\title{
Uzaktan Eğitimle Yürütülen Özel Eğitim Dersine İlişkin Müzik Öğretmeni Adaylarının Görüşleri
}

\section{Opinions of Prospective Music Teachers on the Special Education Course Conducted with Distance Education}

\author{
Cem ASLAN ${ }^{1}$ \\ ${ }^{1}$ Sorumlu Yazar, Dr., Özel Eğitim Bölümü, Gazi Eğitim Fakültesi, Gazi Üniversitesi, Türkiye, \\ cemaslan@gazi.edu.tr, (https://orcid.org/0000-0002-0300-5873)
}

Geliş Tarihi: 10.08.2021

Kabul Tarihi: 27.12.2021

\section{ÖZ}

Bu çalışmanın amacı, müzik öğretmeni adaylarının uzaktan eğitimle yürütülen özel eğitim dersine ilişkin görüşlerini belirlemektir. Çalışma, nitel araştırma modellerinden fenomenoloji desenine göre kurgulanmıştır. 47 müzik öğretmeni adayı çalışmanın katılımcılarını oluşturmuştur. Veri toplamak amacıyla Yarı Yapılandırılmış Görüşme Formu'ndan faydalanılmıştır. Veriler 2019-2020 eğitim-öğretim yılı bahar döneminde toplanmıştır. Verilerin toplanmasında bir devlet ilgili üniversitesinin Uzaktan Eğitim Uygulama ve Araştırma Merkezi'nin altyapı sağladığı Öğrenme Yönetim Sistemi kullanılmıştır. Elde edilen verilerin analizinde içerik analizi tekniği kullanılmıştır. Veriler tema ve alt temalara ayrılarak çözümlenmiş̧ir. Çalışmanın bulgularına göre, özel eğitim dersinin her öğretmen için gerekli ve faydalı bir ders olduğu ve meslek yaşantısına katkı sağlayacağı görüşlerine ulaşılmıştır. Öğretmen adaylarının özel eğitim dersinden bazı beklentilerinin olduğu ve ders sonunda bu beklentilerin önemli ölçüde karşılandığı görülmüş̧ür. Dersin işleniş biçimi ve derste anlatılan konularla ilgili farklı görüşler ortaya çıkmıştır. Bunun yanında, öğretmen adayları özel eğitim dersiyle ilgili bazı istek ve önerilerde bulunmuştur.

Anahtar sözcükler: Özel eğitim, uzaktan eğitim, müzik eğitimi, öğretmen adayı.

\begin{abstract}
This study aims to determine the opinions of prospective music teachers regarding the special education course conducted with distance education. The researcher constructed the survey according to phenomenology, one of the qualitative research models. Forty-seven future music teachers constituted the participants of the study. A semi-structured interview form, which the researchers prepared, was used to collect data. The researcher collected the data in the 2019-2020 academic year. He used the Learning Management System provided by the Distance Education Application and Research Center of the relevant university for data collection. Content analysis technique was used in the analysis of the obtained data. The data were reported by dividing them into themes and sub-themes. According to the study's findings, a special education course is a necessary and valuable lesson for every teacher and will contribute to professional life. The researcher observed that prospective teachers had some expectations from the special education course, and they met these expectations at the end of the period to a great extent. On the other hand, different opinions emerged about how the course was taught and the topics covered. Besides, prospective teachers made some requests and suggestions about special education lessons.
\end{abstract}

Keywords: Special education, distance education, music education, teacher candidate. 


\section{GíRiş}

Ülkemizde müzik eğitimi genellikle alan mezunu müzik ögretmenleri tarafından yürütülmektedir. Müzik öğretmeni, yalın ve özlü anlamıyla "Müzik dalında ögrretmenlik mesleğinin gerektirdiği ögrenimi bitirerek ya da gerekli yeterlikleri kazanarak ögrretmenlik yapma yetkisini elde etmiş öğretmenler" olarak nitelendirilmektedir (Varış, 2013). Günümüzde müzik öğretmenleri, üniversitelerin eğitim fakültelerinin güzel sanatlar eğitimi bölümleri çatısı altında yetiştirilmektedir. Müzik eğitiminden sorumlu olan müzik öğretmenlerinin öğrencilerin eğitim-öğretim ihtiyacını karşılayacak yeterliklere sahip olması beklenmektedir. Bu kapsamda, söz konusu öğretmen adaylarına mesleğin gerektirdiği müziksel davranışların, birikimin ve yeterliklerin kazandırılması amaçlanmaktadır (Uçan, 2018). Müzik alan bilgisi, müziksel davranış biçimleri ile aktif ilişki, müzik öğretimi ve bireysel yeterliklere odaklanılmaktadır (Kalyoncu, 2004). Ek olarak bireylerin çeşitli yeterlikleri kazanabileceği hedeflenmekte; alan bilgisi, müziksel performans ve öğretmenlik mesleğinin gereklerini tanıtacak ve öğretme becerilerini kazandıracak bilgilerin kazandırılması beklenmektedir (Varış, 2013). Bu derslerinden biri de özel eğitim dersi olarak nitelendirilebilir. Müzik öğretmeni adaylarına özel eğitim alanı ve özel gereksinimli bireyler hakkında farkındalık yaratması, mesleğe başladıktan sonra sınıflarında özel gereksinimli öğrencileri fark etmeleri, bu öğrencilerin eğitsel gereksinimlerini belirleyebilmeleri ve karşılayabilmeleri açısından özel eğitim dersinin önemli olduğu düşünülmektedir (Çitil, Karakoç ve Küçüközyiğit, 2018).

Özel eğitimin farklı alan eğitimcileri tarafından iyi tanımlanabilmesi ve kavranabilmesi için tüm öğretmenlik lisans programlarında özel eğitim dersi zorunlu/seçmeli bir ders olarak yer almıştır. Böylelikle, özel eğitim öğretmenliği programlarına ek olarak birçok öğretmenlik programında da özel eğitim dersi zorunlu/seçmeli ders olarak verilmeye başlanmıştır (Çitil vd., 2018). Bu kapsamda, "özel eğitim", yeni adıyla "özel eğitim ve kaynaştırma" dersi müzik öğretmenliği lisans programlarına da dâhil olmuştur. Müzik öğretmenliği programında özel eğitim dersi, ilk kez pedagoji alanı/öğretmenlik meslek bilgisi dersleri (zorunlu) kapsamında (Berki ve Karakelle, 2009) programda yer almıştır. Program ise 2006-2007 y1lından itibaren sekizinci yarıyıl haftada iki saat gerçekleştirilmek üzere yürürlüğe girmiştir.

Özel eğitim dersinin hem özel eğitim alanı hem de özel gereksinimli bireyler hakkında öğretmen adaylarının yeterli bilgi sahibi olmalarını sağlayacak bir içeriğe sahip olduğu ifade edilmektedir (Durdukoca-Fırat, 2015; Yaral1, 2016). Özel eğitim dersinin içeriğinde; özel eğitimle ilgili tanımlar, özel eğitimin ilkeleri, özel gereksinimli olma nedenleri, erken tanı süreci, özel eğitime tarihsel yaklaşım, özel gereksinimli bireylere yönelik tutumlar, yetersizlik türleri ve bunların eğitimleri, özel eğitime gereksinim duyan çocukların aileleri, ülkemizdeki mevcut durum, özel eğitim kurum ve kuruluşları gibi pek çok konu yer almaktadır. Yukarıda da değinildiği üzere güncellenen ve programlarda yer alan yeni adıyla özel eğitim ve kaynaştırma dersinin içeriğinde ise genel itibariyle şu konular bulunmaktadır: Özel eğitimle ilgili temel kavramlar, özel eğitimin ilkeleri ve tarihsel gelişimi, özel eğitimde yasal düzenlemeler, özel gereksinimli bireyleri tanılama ve değerlendirme, öğretimin bireyselleştirilmesi, kaynaştırma ve destek özel eğitim hizmetleri, ailenin eğitime katılımı ve işbirliği, farklı yetersizlik grupları, farklı gruplara yönelik eğitim-öğretim stratejileri, sınıf ve davranış yönetimi. Her iki dersin içerikleri incelediğinde genel olarak benzerliklerin olduğu görülmekle birlikte farklı konu başlıklarının olduğu da söylenebilir.

Alanyazında, özel eğitim dersi üzerine yapılmış çeşitli araştırmalar söz konusudur. $\mathrm{Bu}$ araştırmalarda özel eğitim dersi farklı amaçlar çerçevesinde ele alınmıştır. Örneğin; özel eğitim dersinin kaynaştırmaya (Alat ve Alat, 2007; Altıntaş ve Şengül, 2014), özel gereksinimli bireylere (Alptekin ve Batık, 2013; Aslan ve Kök, 2013; Çitil vd., 2018; Top, 2018) yönelik tutumlara ve bilgi düzeyine etkisi (Çitil vd., 2018), özel eğitim dersine yönelik tutum ölçeği geliştirme (Durdukoca-Fırat, 2015; Yaral1, 2015) ve tutumların incelenmesi (Durdukoca-Frrat, 2017; Yaral1, 2016), özel eğitim dersinin etkililiğinin geliştirilmesi (Melekoğlu, 2011), özel 
eğitim dersindeki kazanımların belirlenmesi (Kösterelioğlu ve Baytemir, 2017) ve özel eğitim dersi etkinliklerine yönelik ihtiyaç analizi (Sarı ve Saygın, 2002) konuları üzerinde durulmuştur.

Bilindiği üzere tüm dünyada olduğu gibi ülkemizde de etkisini gösteren pandemi (COVID-19) nedeniyle Yükseköğretim Kurulu (YÖK) tarafından alınan kararlar doğrultusunda 2019-2020 öğretim dönemi için yüz yüze eğitim askıya alınmıştır (YÖK, 2020). Bu durum, yükseköğretim kurumlarının eğitim-öğretim faaliyetlerinde bazı aksaklıkların yaşanmasına neden olmuştur (Karatepe, Küçükgençay ve Peker, 2020). Bununla beraber, uzaktan eğitimle ilgili teknik, psikolojik veya sosyal boyutlar açısından çeşitli sorunların yaşandığ 1 ifade edilmektedir (Karakuş, Ucuzsatar, Karacaoğlu, Esendemir ve Bayraktar, 2020). Bunun neticesi olarak eğitim-öğretim süreçlerinde aksaklık yaşanmaması için bazı tedbirler alınmıştır. Yükseköğretim kurumlarının örgün eğitimden uzaktan eğitime geçmeleri alınan en önemli tedbirlerden biridir (Kalaç, Telli ve Eronal, 2020). Buna göre, uzaktan eğitim ve/veya uzaktan eğitim süreci konularında yapılacak çalışmaların büyük önem arz edeceği ifade edilebilir. Bu çalışma ise söz konusu bu önemin varlığından hareketle planlanmış ve özel eğitim dersinin uzaktan eğitimle verilmesine ilişkin görüşler irdelenmiştir. Çünkü özel eğitim dersi, geleneksel olarak yüz yüze olacak şekilde sınıf ortamında yürütülen teorik derslerden biridir. Ancak pandemi dolayısıyla alınan kararlar neticesiyle bu ders uzaktan eğitimle devam ettirilmiştir. $\mathrm{Bu}$ süreçte, özel eğitim dersini uzaktan eğitimle alan öğretmen adaylarından bir grup da çalışmanın katılımcılarını oluşturan müzik öğretmeni adaylarıdır. Dolayısıyla, çalışmada uzaktan eğitimle özel eğitim dersini alan müzik öğretmeni adaylarının görüşlerine odaklanılmıştır.

Öğretmen adaylarının görüşleri veya düşünceleri; öğrencilerine yaklaşımlarına olduğu kadar eğitim-öğretim hizmetlerini de etkileyebilmektedir (Heward, Alber-Morgan ve Konrad, 2017). Bu bakımdan özellikle özel eğitim alanı haricindeki diğer branşlardan öğretmen adaylarının görüş alg1, tutum gibi özelliklerinin belirlenmesi önemli görülmektedir. Müzik öğretmeni adaylarına özel eğitim alanı ile ilgili olarak farkındalık kazandırabilmek, mesleğe başladıktan sonra özel gereksinimli öğrencileri fark edebilmeleri aynı zamanda bu öğrencileri desteklemelerini sağlayabilmeleri açısından özel eğitim dersinin önemli bir yere sahip olduğu ifade edilebilir. Bu doğrultuda, müzik öğretmeni adaylarının eğitiminde etkili olabilecek ve farkındalık oluşturabilecek özel eğitim dersinin uzaktan eğitimle yürütülmesine ilişkin görüşlerin belirlenmesi amaçlanmıştır. Mevcut koşullar altında pandeminin ve uzaktan eğitim uygulamalarının devam ediyor olması, yapılan çalışmanın güncel yönünü yansıtmaktadır. Alanyazın incelendiğinde, özellikle son birkaç yılda özel eğitim alanında uzaktan eğitim süreci ile ilgili çeşitli konularda pek çok araştırma yapılmıştır (örn., Akbayrak, Vural ve Ağar, 2021; Börnert-Ringleb, Casale ve Hillenbrand, 2021; Frederick, Raabe, Rogers ve Pizzica, 2020; Kizir, 2021; Sani-Bozkurt vd., 2021; Ünay, Erdem ve Çakıroğlu, 2021). Söz konusu bu araştırmalarda uzaktan eğitim uygulamaları, bu uygulamalara ilişkin uzman görüşleri, özel eğitim öğretmenlerinin uzaktan eğitim deneyimleri, uzaktan eğitim alan bireylerin görüşleri, özel eğitim destek hizmetler modeli önerisi, dijital öğrenmenin önündeki engeller gibi konular ele alınmıştır. Ancak mevcut araştırmalara bakıldığında, doğrudan veya dolaylı olarak uzaktan eğitim ile sunulan özel eğitim dersine yönelik görüşleri ele alan araştırmaya ulaşılmamıştır. Bu açıdan yapılan çalışma önemli görülmekle beraber alanyazına katkı sunması beklenmektedir. Yapılan bu çalışmada, özel eğitim dersinin uzaktan eğitimle yürütülmesine yönelik müzik öğretmeni adaylarının görüşlerine başvurarak özellikle öğrenci-öğretim elemanı etkileşimi sürecinde özel eğitim dersinin içeriği ve bu dersin kazanımlarının müzik eğitimi alanına katkısına yönelik tespitlerin yapılabileceği, ayrıca ileriki öğretmenik yaşantılarına yönelik uygulama çıktılarının incelenebileceği düşünülmektedir. 


\section{YÖNTEM}

\subsection{Araştırmanın Deseni}

Çalışmada, nitel araştırma modellerinden fenomenoloji kullanılmıştır. Bu desenle yürütülen çalışmalarda, bireylerin bizzat deneyimlediği olgular veya olaylar hakkındaki düşüncelerine yakından bakılarak, zihinlerindeki bilişsel yapıların, deneyimlerin ve düşüncelerin açığa çıkarılması hedeflenmektedir (Yıldırım ve Şimşek, 2005). Diğer bir ifadeyle, fenomenoloji araştırmalarında bir olguya ya da duruma yönelik sahip olunan deneyimler ile bu deneyimlerden ulaşlan anlamlar derinlemesine incelenmekte (Patton, 2014) ve bireylerin belirli bir olguya veya kavrama ilişkin deneyimlerinden ortak anlamlar keşfedilmesi hedeflenmektedir (Cresswell, 2007). Bu yönüyle, müzik öğretmeni adaylarının uzaktan eğitimle yürütülen özel eğitim dersine ilişkin görüşlerinin belirlenmesini amaçlayan bu çalışmanın fenomenoloji araştırması olduğu ve görüşlerin derinlemesine incelenebilmesi açısından bu yöntemin etkili bir desen olduğu ifade edilebilir. Fenomenoloji araştırmalarında olgulara ilişkin yaşantıları ve anlamları ortaya çıkarmak amacıyla görüşmelerden yararlanılır (Büyüköztürk, Kılıç Çakmak, Akgün, Karadeniz ve Demirel, 2012). Bu çalışmada da müzik öğretmeni adaylarıyla yarı yapılandırılmış görüşmeler yapılmış ve analiz edilmiştir.

\subsection{Katılımcilar}

Çalışmanın katılımcıları, 2019-2020 eğitim öğretim yılında bir devlet üniversitesinin eğitim fakültesinde öğrenim gören müzik öğretmeni adaylarıdır. Bu kapsamda uzaktan eğitim yöntemiyle özel eğitim dersini alan 47 öğretmen adayı çalışmanın katılımcılarını oluşturmuştur. Katılımcıların 34'ü kız (\%72.3), 13'ü erkektir (\%27.7). Katılımcıların yaşları 22 ile 36 arasında değişmektedir. Katılımcılar, bu dönem özel eğitim dersini ilk defa almışlardır. Dersi alan bütün öğretmen adayları çalışmaya gönüllü olarak katılmışlardır.

\subsection{Veri Toplama Aracı}

Çalışmada, veri toplamak amacıyla araştırmacı tarafından oluşturulan yarı yapılandırılmış görüşme formu kullanılmıştır. Yarı yapılandırılmış görüşme formları, görüşülen kişilerin kendilerini daha iyi ifade etme imkanı ve derinlemesine bilgi sunmaktadır (Büyüköztürk vd., 2012). Görüşme formu ilgili literatürden ulaşılan araştırmalar (örn., Çay, 2020; Çitil vd., 2018; Kan ve Fidan, 2016; Karakuş vd., 2020; Varış, 2013) doğrultusunda hazırlanmıştır. Formun kapsam geçerliliği için üç farklı alan uzmanından (özel eğitim, müzik eğitimi, Türkçe eğitimi) görüş alınmıştır. Ayrıca, uzaktan eğitim yöntemiyle özel eğitim dersini alan ancak katılımcılar arasında olmayan iki öğretmen adayıyla pilot görüşme gerçekleştirilmiştir. Bu görüşmeler doğrultusunda soruların anlaşılırlığı, açık ve net olması gibi hususlara dikkat edilerek gerekli değişiklikler yapılmıştır. Sonuç olarak, iki sorunun içeriğinde değişikliğe gidilerek ve bir sorunun ifade şekli düzeltilerek altı soruyu içeren görüşme formu nihaî hale getirilmiştir. Görüşme formunun ön kısmına öğretmen adaylarının bilgilerini alabilmek için cinsiyet, yaş, özel eğitim dersini alıp almadığı gibi demografik maddeler eklenmiştir.

\subsection{Verilerin Toplanması}

Veri toplama sürecinde öncelikle gerekli etik izinler alınmıştır (Gazi Üniversitesi, 06.10.2020. Sayı No: 91610558-604.01.02). Veriler 2019-2020 eğitim-öğretim yılında toplanmıştır. Veri toplamak için öğretmen adaylarına e-posta ile ulaşılarak yapılacak çalışma hakkında bilgi verilmiştir. Görüşmelerden elde edilecek dökümlerin başka bir yerde kullanılmayacağı, herhangi bir ismin kullanılmayacağı (kod verileceği), verilerin bilimsel amaçla değerlendirileceği ve talep etmeleri halinde sonuçların kendilerine iletilebileceği yazılı olarak aktarılmıştır. Ek olarak katılımın gönüllülük esasına dayalı olduğu ve görüşmeye katılıp katılmama konusunda özgür oldukları belirtilmiştir. Bunun için yine e-posta üzerinden gönderilen Gönüllü Katılım Formu kullanılarak öğretmen adaylarından teyit alınmıştır. 
Çalışmanın verileri öğretmen adaylarının yazılı beyanlarına dayalı olarak alınmıştır. Verilerin toplanmasında, ilgili üniversitenin uzaktan eğitim merkezinin altyap1 sağladığ 1 Öğrenme Yönetim Sistemi’nden (ÖYS) yararlanılmıştır. Bu yönüyle, ilk olarak görüşme soruları ÖYS üzerinden öğretmen adaylarının kayıtlı e-postalarına gönderilmiştir. Öğretmen adaylarına 15 günlük süre tanınmıştır. Öğretmen adayları görüşme formlarını tekrar araştırmacıya e-posta aracılığıyla iletmişlerdir. Bu süre zarfında özel eğitim dersini alan 47 öğretmen adayının tamamı araştırmacıya dönüş yapmıştır.

\subsection{Verilerin Analizi}

Öğretmen adaylarından gelen yanıtlar neticesinde toplam 101 sayfa veri elde edilmiştir. Verilerin analizinde içerik analizi yönteminden faydalanılmıştır. İçerik analizi "Birbirine benzer verileri bir araya getirerek anlamlı tema(lar) oluşturabilmek, elde edilen verileri okuyucuların anlayabileceği şekilde organize bir biçimde açıklayan analiz yöntemidir." (Yıldırım ve Şimşek, 2005). Çalışmada öğretmen adaylarının sorulara verdiği yanıtlar araştırmacı tarafından tek tek okunarak, verilerin içerisindeki anlamlı bölümler tespit edilmiştir. Daha sonra bu bölümler tekrar incelenerek söz konusu bölümleri en iyi ifade edecek bir kavram, sözcük veya cümle ile işaretlenmiştir. Böylelikle görüşme metinleri analiz edilmeye başlanmıştır. Bu kapsamda, görüşmelerin yazılı dökümleri çalışmanın amacı çerçevesinde kodlanmıştır. Kodlanan veriler araştırmacı tarafından sınıflandırılmış ve bu kodları en iyi şekilde temsil edecek temalar oluşturulmuştur. Özellikle uzun yanıtı olan sorular, yanıtın ana fikrini değiştirmede araştırmacı tarafından kısaltılmıştır. Öğretmen adaylarının görüşleri belirlenen tema ve alt temalar ile gösterilmiştir (Tablo 1). Gerekli durumlarda öğretmen adaylarının görüşlerinden alıntılar verilmiştir. Bulguların raporlaştırılmasında "temaya uygunluk", "açıklayıcıllk" ve "çarpıcılık" ölçütleri göz önünde bulundurularak birbirini destekleyecek nitelikteki alıntılara yer verilmiş ve temalar açıklanmaya çalışılmıştır (Ünver, Bümen ve Başbay, 2010). Bu alıntılar yapılırken öğretmen adaylarının gizliliğini koruyabilmek amacıyla her bir öğretmen adayına "Ö${ }_{1}, \ddot{\mathrm{O}}_{2}, \ddot{\mathrm{O}}_{3}$ " şeklinde kod atanmıştır.

Tablo 1. Analiz Sonucu Elde Edilen Tema ve Alt Temalar

\begin{tabular}{|c|c|}
\hline Temalar & Alt Temalar \\
\hline $\begin{array}{l}\text { Özel Eğitim Dersine } \\
\text { İlişkin Görüşler }\end{array}$ & $\begin{array}{ll}\text { - } & \text { Her öğretmen için gerekli bir ders } \\
\text { - } & \text { Daha fazla hassasiyet gerektiren bir ders }\end{array}$ \\
\hline $\begin{array}{l}\text { Özel Eğitim Dersinin } \\
\text { Katk1ları }\end{array}$ & $\begin{array}{ll}\text { - } & \text { Faydalı bir ders } \\
\text { - } & \text { Meslek yaşantılarında katkı sağlayacak bir ders } \\
\text { - } & \text { Pek çok yeni bilgi öğrendikleri bir ders }\end{array}$ \\
\hline $\begin{array}{l}\text { Özel Eğitim Dersinden } \\
\text { Beklentiler }\end{array}$ & $\begin{array}{ll}\text { - } & \text { Özel eğitime gereksinimi olan çocuklara nasıl davranacağımı öğrenebilmek } \\
\text { - } & \text { Özel eğitime gereksinimi olan ögrencileri tanıyabilmek } \\
\text { - } & \text { Özel eğitime gereksinimi olan çocukları derse katabilmek } \\
\text { - } & \text { Özel gereksinimli öğrencilerin gelişimlerini destekleyebilmek } \\
\text { - } & \text { Özel eğitime gereksinimi olan çocuklarla iletişim kurabilmek } \\
\text { - } & \text { Müziğe yeteneği olan özel gereksinimli öğrencileri fark edebilmek } \\
\text { - } & \text { Özel eğitime gereksinimi olan öğrencilerle normal öğrencileri kaynaştırabilmek }\end{array}$ \\
\hline $\begin{array}{l}\text { Özel Eğitim Dersinde } \\
\text { Anlatılan Konular }\end{array}$ & $\begin{array}{ll}\text { - } & \text { Tüm konuların üzerinde yeterince duruldu } \\
\text { - } & \text { Bazı konuların üzerinde daha fazla durulmalı } \\
\text { - } & \text { Konular uzun ve detaylı } \\
\text { - } & \text { Alanımıza özgü konuların üzerinde daha fazla durulmalı } \\
\text { - } & \text { Bazı konuların yetersiz kaldı } \\
\end{array}$ \\
\hline Dersin İ̧̧leniş Biçimi & $\begin{array}{ll}\text { - } & \text { Video, görüntü, canlandırma vb. etkinliklere ve öğretim materyallerine daha fazla } \\
& \text { yer verilmeli } \\
\text { - } & \text { Görsel içeriğin yeterli düzeyde } \\
\text { - } & \text { Uygulama yapma imkânı olmadı } \\
\text { - } \quad \text { Ders materyali geliştirme sürecine ağırlık verilmeli }\end{array}$ \\
\hline Öneriler/İstekler & $\begin{array}{ll}\text { - } & \text { Öğretmenlerin tecrübe ve izlenimlerini dinleme } \\
\text { - } & \text { Müzik eğitimi alanına yönelik ayrı bir dersin daha olmalı } \\
\text { - } & \text { Doğrudan okullarda gözlem/uygulama yapabilme } \\
\text { - } & \text { Özel gereksinimi olan öğrenciler ile doğrudan iletişim kurabilme } \\
\text { - } & \text { Alan çalışmaları üzerinde tartışma ve ortak fikirler geliştirme } \\
\end{array}$ \\
\hline
\end{tabular}




\subsection{Geçerlik ve Güvenirlik}

Nitel çalışmalarda, araştırmacıların geçerlik ve güvenirliğe ilişkin dikkate alması gereken bazı hususlar vardır (Creswell, 2016). Geçerlik ve güvenirlik çalışmaları için toplanan verilerin ayrıntılı bir şekilde raporlanması ve aynı zamanda sonuçlara nasıl ulaşıldığının açılanması gerekir (Yıldırım ve Şimşek, 2005). Nitel çalışmalarda geçerlik ve güvenirlik gibi kavramların yerine, inandırıcılık ve aktarılabilirlik gibi kavramlar daha fazla kullanılmaktadır (Koşar, 2018). $\mathrm{Bu}$ nedenle ulaşılan bulguların tutarlı ve anlamlı olması, aynı zamanda bir bütün oluşturması gerekir. Ek olarak bulgular katılımcılar tarafindan gerçekçi bulunmalı ve bulguların teyidi için uygun stratejilerin kullanımına yer verilmelidir (Miles ve Huberman, 2015). Bu çalışmanın bulgularına öğretmen adaylarının yazılı olarak beyan ettikleri görüşlerine bağlı olarak ulaşılmıştır. Bu doğrultuda uzman görüşü, katılımcı teyidi, öğretmen adaylarının görüşlerinden doğrudan alıntılar, veri toplama aracıyla bulguların alanyazınla desteklenmesi ile iç geçerliğin sağlanması amaçlanmıştır. Dış geçerlik için çalışma aşamalarının tanımlanması, veri toplama süreci, verileri kodlama, analiz etme ve yorumlama süreçlerinin ayrıntılı olarak açıklanması, kişisel önyarg1 veya görüşlerin bulgulara yansıtılmaması, verilerin incelemeye uygun bir şekilde korunması ile sağlanmaya çalışılmıştır. Ayrıca, nitel araştırmalarda ulaşılan verilerin kodlanmasında kodlamacılar arası güvenirlik incelemesi yapılmakta ve güvenirliğin $\% 90$ aralığında olması beklenmektedir (Miles ve Huberman, 2015). Bu çalışmada, "Güvenirlik = Görüş Birliği / (Toplam Görüş Birliği + Toplam Görüş Ayrılığı)" formülü kullanılarak yapılan değerlendirme sonucunda $\% 91$ oranında bir uzlaşma olduğu tespit edilmiştir.

\section{BULGULAR}

\subsection{Uzaktan Eğitimle Yürütülen Özel Eğitim Dersine İlişsin Görüşler}

Öğretmen adaylarına yöneltilen ilk soru "Bu dönem uzaktan eğitimle aldığınız özel eğitim dersi hakkında neler söyleyebilirsiniz?” şeklindedir. Verilen yanıtlar incelendiğinde özel eğitim dersini; her öğretmen için gerekli ve daha fazla hassasiyet gerektiren bir ders olarak değerlendirmişlerdir.

Özel eğitim dersinin her öğretmen için gerekli olduğu sekiz öğretmen adayı tarafindan belirtilmiştir. ${ }_{20}$ görüşlerini, “Özel eğitim dersinin, her ögretmenin almasl gereken bir ders olduğunu düşünüyorum. Her öğretmen özel eğitim veren okullarda çalışmayacak olmasına răgmen, bulunduğu okulda kaynaştırma ögrencileri olabilmektedir."; Ӧ ${ }_{15}$ "Özel ĕgitim okullarında çalışmasak bile, çalıştığımız kurumlarda kaynaştırma öğrencileri bulunabileceği göz önünde bulundurularak, özel eğitime ihtiyaç duyabilecek ögrencilerin özelliklerini ve bu ögrencilere nasıl yaklaşmamız ve eğitim vermemiz gerektiğini bilmemizin önemli olduğunu düşünüyorum." şeklinde görüş bildirmiştir. Öğretmen adayları özel eğitimle ilgili bilgi ve donanıma sahip öğretmenlerin yetişmesini belirtmişlerdir. $\ddot{O}_{23}$ "Özel eğitime gereksinimi olan bireyler ile ilgili bilgisi olmadan mezun olan bir ögrretmen topluluğu olsun istemiyorum.”; Ö 8 "Her öğretmen adayının özel ĕgitim hakkında donanıml bilgiye sahip olması gerektiğini düşünüyorum." şeklinde görüşlerini dile getirmiştir. Özel eğitim dersinin diğer derslere göre daha fazla hassasiyet gerektiren bir ders olduğu üç öğretmen adayı tarafindan belirtilmiştir. Ö ${ }_{10}$ "Özel ĕgitim dersi, diğerlerine oranla çok daha bilgi, beceri, özen gerektiren bir derstir."; ${ }_{14}$ "Birçok dersten farklı olarak insanın kalbine dokunmayı başarabilen bir derstir." şeklinde görüş belirtmiştir.

\section{2. Özel Eğitim Dersinin Katkıları}

Öğretmen adaylarına yöneltilen ikinci soru "Uzaktan eğitimle yürütülen özel eğitim dersinde sunulan bilgilerin, meslek yaşantınıza katkıları hakkında ne düşünüyorsunuz?" şeklindedir. Öğretmen adaylarının cevapları değerlendirildiğinde; özel eğitim dersinin faydalı 
bir ders olduğunu, meslek yaşantılarında katkı sağlayacağını ayrıca bu ders kapsamında pek çok yeni bilgi öğrendiklerini vurgulamışlardır.

Özel eğitim dersinin faydalı bir ders olduğu 20 öğretmen adayı tarafindan belirtilmiştir. $\ddot{\mathrm{O}}_{3}$ "Bizim için çok faydalı bir ders oldu. "; ${ }_{15}$ "Özel eğitim dersi kapsamının bize çok faydalı bilgiler kazandırdiğın dü̈sünüyorum.", Ö${ }_{16}$ "Ö̈el eğitim dersinin bana ve ayrıca benim alanıma çok fazla şey kattığını düşünüyorum." şeklinde görüşlerini dile getirmiştir. Öğretmen adaylarının büyük çoğunluğu $(n=42)$ özel eğitim dersinin meslek yaşantılarına katkı sağlayacağ görüşündedirler. "Özel eğitim dersinde sunulan bilgilerin, bir müzik ögretmeni adayı olarak meslek yaşamıma birçok katkısı olacağını düşünüyorum." (Ӧ $\left.{ }_{38}\right)$ ve "Kesinlikle katkıları olacağını düşünüyorum." (Ö̈6) şeklindeki ifadeler örnek olarak sunulabilir. Bazı öğretmen adayları bu katkılara ilişkin daha açıklayıcı ifadeler kullanmıştır. Örneğin; Ö gereksinimi olan bireylerin tespit edilmesinde ve onlar derse katmak, onlara ulaşabilmek konusunda aldı̆̆ımız bilgilerin bize çok katkısı olacağını düşünüyorum.”; $\ddot{O}_{34}$ "Bu dersle birlikte sorunlar karşısında nasıl bir yol izlemem gerektiğini öğreniyorum bu yüzden meslek hayatıma katkı sağlayacağını düşünüyorum." şeklinde açıklamada bulunmuştur. Ö 42 "Müzik ögretmeni aday olarak meslek yaşantısinda özel eğitime gereksinim duyan çocuklarla da karşılaşacağımız düşünülürse özel eğitim dersinin önemi ve katkısı bizim için büyüktür. "; Ö10 "Meslek hayatımızda bizlerin özel eğitime ihtiyaç duyan öğrencilerle ve bireylerle karşılaşılması durumunda sistemli, bilgili, donanıml, iletişim kurmaya elverişli müzik ögretmenleri olmamı adına katkısının yadsınamayacak düzeyde olduğunu açıkça belirtebiliyorum. "şeklinde görüşlerini açıklamışlardır.

17 Öğretmen adayı bu ders kapsamında pek çok yeni bilgi öğrendiklerini ifade etmişlerdir (Şekil 1). Bunlardan ilki özel eğitimin ne olduğunun öğrenilmesidir. Bu konuda $\mathrm{Ö}_{45}$ "Bu dersten ögrendiğim özel eğitimin ne olduğudur." şeklinde görüş belirtmiştir. Diğer görüşler kavramlar ve ders içeriği ile ilgilidir. $\ddot{O}_{32}$ "Dersin bana kattı̆̆ en önemli bilgi anlam ve kavram karmaşalarını ortadan kaldırabilmem oldu." şeklinde görüş beyan etmiştir. İkincisi ise pek çok yeni bilginin öğrenilmiş olduğu yönündedir. $\ddot{O}_{12}$ "Öğrencilerimizle nasıl iletişim kurabileceğimizi, nasıl davranabileceğimizi, işlenen dersin genel kontrolünü nasıl sağlayabileceğimizi ögrendik." şeklinde görüşünü ifade etmiştir. Ö ${ }_{40}$ "Bu ders sayesinde onlara nasıl yaklaşmam gerektiğini öğrendim.”; Ö 44 "Onlara karşı nasıl davranmam gerektiğini, derslerde nasıl onlara karşı etkin ve iyi bir yaklaşım içerisinde olabileceğimi bu ders sayesinde ögrenmiş oldum.” şeklinde açıklamada bulunmuştur. Diğer öğretmen adayları özel eğitim dersinden edindikleri bilgiler hakkında genel kanaatlerde bulunmuşlardır. Ö${ }_{39}$ 'un "Öğretmenlik yaşamımızda ihtiyaç olduğunda yararlanabileceğimiz çok değerli ve oldukça kapsamlı bilgiler edindik."; Ö 45 'in "Özel eğitim dersinde sunulan bilgiler farklılıkları tanımam açısından neler yapmam gerektiği hakkinda ve bu bilgeleri alanıma nasıl aktarmam gerektiği konusunda bana ufuk açıcı bir yol sağladı." tarzındaki görüşleri bu genel kanaatlere örnek teşkil edebilir.

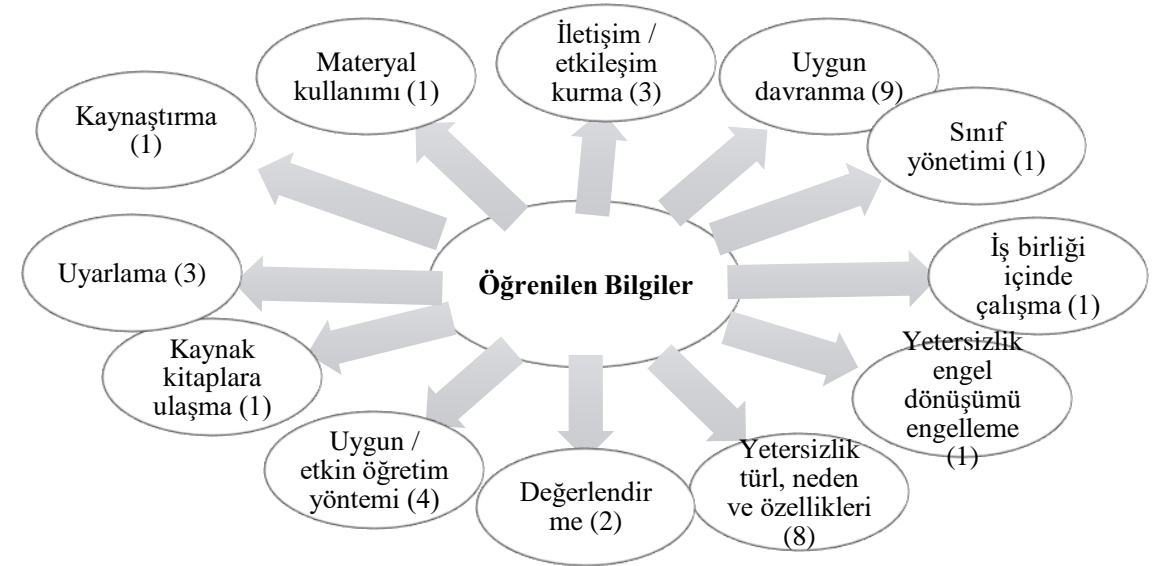

Şekil 1. Öğretmen Adaylarının Özel Eğitim Dersinde Öğrendikleri Bilgiler 


\section{3. Özel Eğitim Dersinden Beklentiler}

Öğretmen adaylarına yöneltilen üçüncü soru "Uzaktan eğitimle yürütülen özel eğitim dersinden beklentileriniz nelerdi? Dersin sonunda, beklentilerinizin karşılanıp/karşılanmadığı hakkında ne düşünüyorsunuz?" şeklindedir. Verilen yanıtlara bakıldığında Şekil 2'de sunulan başlıklarda öğretmen adaylarının farklı beklentilerinin olduğu ve genel olarak bu beklentilerinin önemli ölçüde karşılandığı görülmektedir.

(13)

- Özel eğitime gereksinimi olan çocuklara nasıl davranacağımı öğrenebilmek

(7)

(6)

- Özel eğitime gereksinimi olan öğrencileri tanıyabilmek

- Özel eğitime gereksinimi olan çocukları derse katabilmek

(6)

- Özel gereksinimli öğrencilerin gelişimlerini destekleyebilmek

(3)

(2)

• Özel eğitime gereksinimi olan çocuklarla iletişim kurabilmek

- Müziğe yeteneği olan özel gereksinimli öğrencileri fark edebilmek

(1)

• Özel eğitime gereksinimi olan öğrencilerle normal öğrencileri kaynaştırabilmek

Şekil 2. Öğretmen Adaylarının Özel Eğitim Dersinden Beklentileri

Özel eğitime gereksinimi olan çocukları derse katabilmek: "Bu dersten beklentim özel eğitime ihtiyaç duyan bir ögrenciyi derste nasıl aktif kılabilirim? Ne kadar aktif kılabilirim? Bunlart ögrenmekti." (Ӧ̈14).

Özel eğitime gereksinimi olan çocuklarla iletişim kurabilmek: ${ }_{34}$ "Bu dersten beklentim özel eğitime ihtiyacı olan bir ögrenciyle sağllklı bir şekilde iletişime geçebilmek.” şeklinde görüş beyan etmiştir.

Özel eğitime gereksinimi olan çocuklara nasıl davranacağımı öğrenebilmek: Ö 6 " $B u$ dersten beklentim günlük hayatımda ve meslekî hayatımda karşıma çıkabilmesi muhtemel özel bireylere karşı davranıșlarımda bilmem gereken önemli bilgilere sahip olmak."; $\ddot{O}_{29}$ "Özel eğitim dersi için beklentilerim arasında onlara karşı nasıl davranmam gerektiğini nasıl yaklaşımda bulunmam gerektĭgi nelerin doğru nelerin yanlış olduğunu ögrenmekti.”; Ӧ 46 "Özel eğitim dersinden beklentim sinıfta veya okulda bir özel öğrenci olduğunda nasıl davranacağımı ögrenmekti."; $\mathrm{O}_{12}$ "Bu bireylere nasıl yaklaşmamı gerektiğini, bir ortamda nasıl davranmamız gerektiğini ve nasıl yardımcı olmamız gerektiğini öğrenmek istiyordum." şeklinde görüşlerini ifade etmiştir.

Özel gereksinimli öğrencilerle normal öğrencileri kaynaştırabilmek: "Hem yetersizliği olan hem de diğer ögrencilerin birbirlerini yadırgamadan davranmaların nasıl ögretmem gerektiğini öğrenmeyi bekliyorum." $\left(\mathrm{O}_{7}\right)$.

Özel eğitime gereksinimi olan öğrencileri tanıyabilmek: "Bu dersten beklentim özel çocuklarımızın durumunu daha yakından tanıyabilmek ve onları ruhsal, bedensel ve bilişsel olarak gelişimlerini daha iyi anlayabilmek." (Ö̈ ${ }_{1}$ şeklinde görüş belirtmiştir.

Müziğe yeteneği olan özel gereksinimli öğrencileri fark edebilmek: "Bu derste müziğe yeteneği olan özel çocuklarımızın fark edilmesi, geliştirilmesi, yönlendirilmesi yönünde bilgi edinmeyi bekliyorum." $\left(\mathrm{O}_{3}\right)$.

Özel gereksinimli öğrencilerin gelişimlerini destekleyebilmek: ${ }_{16}$ "Bu dersten beklentim özel durumu olan çocuklara nastl destek olabileceğimi ögrenmekti." $\mathrm{O}_{36}$ "Bu dersten 
beklentilerim özel eğitime ihtiyacı olan bireylere yardımcı olabilmek ve ögrencilerimizi bu konuda destekleyebilmekti." şeklinde düşüncelerini ifade etmişlerdir.

Son olarak, öğretmen adaylarının büyük bir çoğunluğu $(n=35)$ özel eğitim dersinde beklentilerinin karşılandığını açıklamışır. "Beklentilerimi fazlasıyla karşılamış durumda." $\left(\ddot{O}_{31}\right)$ ve "Beklentilerimin olumlu açıdan karşılandı̆̆ını düşünüyorum." $\left(\ddot{O}_{20}\right)$ şeklindeki ifadeler beklentilerin karşılandığı yönündeki görüşlere örnek teşkil edebilir.

\section{4. Özel Eğitim Dersinde Anlatılan Konular}

Öğretmen adaylarına yöneltilen dördüncü soru "Uzaktan eğitimle yürütülen özel eğitim dersinde anlatılan konular hakkında ne düşünüyorsunuz?" şeklindedir. Verilen yanıtlar incelendiğinde; tüm konuların üzerinde yeterince durulduğu, bazı konuların üzerinde daha fazla durulması gerektiği, konuların uzun ve detaylı olduğu ve bazı konuların yetersiz kaldığı yönünde görüşler ortaya çıkmıştır.

Tüm konuların üzerinde yeterince durulduğu görüşünde olan öğretmen adayları $(n=17)$ görüşlerini şu şekilde dile getirmişlerdir: "Özel eğitim dersinde, uzaktan eğitim sürecinde her konunun üzerinde yeterince durulduğunu düşünüyorum." (Ӧ $\left.{ }_{44}\right)$; "Bu süreç içerisinde birçok alanda yetersizliği olan öğrenciler bölüm bölüm anlatıldı. Sinıfimızda ne tür bir yetersizliği olan ögrenci olabileceği bilinemediği için, hepsinden bahsedilmesi ve anlatılması bence yerinde bir uygulama oldu." $\left(\ddot{\mathrm{O}}_{20}\right)$.

Bazı konuların üzerinde daha fazla durulması gerektiği yönünde görüş bildiren öğretmen adayları $(n=25)$ bulunmaktadır. Öğretmen adaylarının ifadeleri incelendiğinde, bu konuların çeşitlilik arz ettiği görülmektedir (Şekil 3). Örneğin görme yetersizliği, işitme yetersizliği ve zihin yetersizlik konuları üzerinde daha fazla durulması gerektiği yönünde görüşlere ulaşılırken bu konuların ise çeşitlilik arz ettiği görülmektedir. Öğretmen adaylarının görüşleri şu şekilde örneklendirilebilir: "Alanımız gereği daha çok işitme yetersizliği konusunun üstünde durulması gerektiğini düşünmekteyim." (Ö̈ $\left.{ }_{13}\right)$; "Müzik eğitimi alanında en çok rastladığımız görme engelli ögrenciler üzerinde belki de daha fazla durabilirdik." (Ӧ $\left.{ }_{24}\right)$; "Zihinsel yetersizlik konusu üzerinde daha fazla durulması gerektiğini düşünüyorum." (ОО $\left.{ }_{25}\right)$; "Duygusal ve davranışsal bozukluğu olan çocuklar üzerinde daha fazla durulması gerektiğini düşünüyorum." (Ӧ $\left.{ }_{37}\right)$; "Konuşma ve dil bozukluğu konusunun üzerinde durulması gerektiğini düşünüyorum." ( $\left.\ddot{O}_{36}\right)$. Ek olarak "Kaynaştırma konusundan daha fazla bahsedilebilir." ( $\left.\mathrm{O}_{38}\right)$ ve "Kaynaştırma uygulamaları konusunda daha fazla durulması gerektiğini düşünüyorum." ((Ӧ $\left.{ }_{27}\right)$ şeklinde görüşlere de ulaşılmıştır.

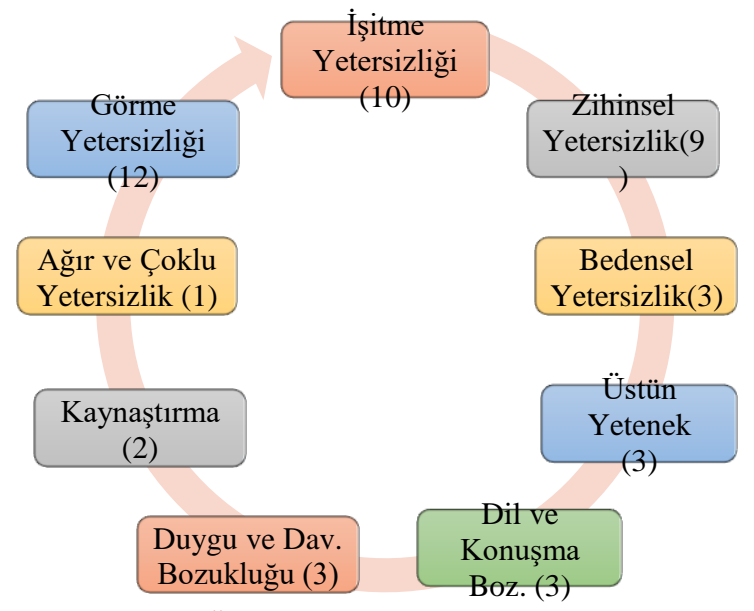

Şekil 3. Özel Eğitim Dersinde Üzerinde Daha Fazla Durulması Gereken Konular

Öğretmen adaylarından sekizi konuların uzun ve detaylı olduğunu vurgulamışlardır. Bu konuya örnek ifadeler: "Özel ĕgitim dersi için yarım dönemlik ders süresinin yeterli olmadiğını 


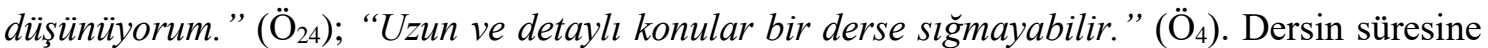
dikkat çeken ifadeler ise şu şekildedir: "Bence dersin süresi yetersizdi, biraz daha uzun bir ders olsaydı konuları yaya yaya anlatılabilseydi daha iyi olabilirdi." (Ӧ $\left.{ }_{46}\right)$; "Bu ders daha çok teori dersi olduğu için, süresi kısıtlı olduğu için ve malûm bu dönemde uzaktan eğitimle yapıldı̆̆ için sadece anlatım yapılması uygun oluyor." ( $\left.\mathrm{O}_{39}\right)$.

Alanımıza özgü konuların üzerinde daha fazla durulması gerektiği 13 öğretmen adayı tarafından ortaya konmuştur. $\ddot{O}_{1}$, "Alanımız doğrultusunda nasıl eğitim vermemiz gerektiği konusunun biraz daha üzerinde durulması gerektiğini düşünüyorum."; ${ }_{3}$, "Kendi alanımız dahilinde bu çocukların müzik derslerinde nasıl geliştirileceği, yönlendirileceği, hangi yöntem ve tekniğin uygulanmast gerektiği üzerinde daha fazla durulmalıydl."; $\ddot{\mathrm{O}}_{2}$, "Engel durumuna göre müzik dersi en faydalı nasll işlenebilir konusu hakkında tartışmanın ve üstünde fazla durulmasının meslek hayatımızda daha çok işimize yarayacă̆ını düşünüyorum." şeklinde görüşlerini açıklamışlardır. Bunlardan farklı olarak bir öğretmen adayının görüşleri farklılık göstermiştir: "Müzik dersine yönelik özel eğitim dersi olmasını beklerdim." (Ӧ 43 ).

Öğretmen adaylarından üçü bazı konuların yetersiz kaldığını belirtmişlerdir. Örnek ifadeler olarak "Bu dersin söyleyebileceğim tek eksik kalan yanı ögrenilenleri kendi alanımda nasıl kullanırım? Özel çocuklara müziği ögretirken ne tür etkinliklerden, yöntem ve teknikten faydalanabilirim? konusu oldu." ( $\left.\mathrm{O}_{3}\right)$; "Müziğe ilgi ve yeteneği olan engelli ögrencilerin bu alanda nasıl geliştirileceği ve yönlendirileceği hakkında uygulamalı ve teorik yöntem ve tekniklerin öğretimi eksik düzeyde kalmıştır." (Ö̈

\subsection{Dersin İşleniş Biçimi}

Öğretmen adaylarına yöneltilen beşinci soru "Uzaktan eğitimle yürütülen özel eğitim dersinin işleniş biçimiyle ilgili olarak neler söyleyebilirsiniz?" ş̧eklindedir. Öğretmen adaylarının yanıtları değerlendirildiğinde; video, görüntü, canlandırma vb. etkinliklere ve öğretim materyallerine daha fazla yer verilmesi gerektiği, görsel içeriğin yeterli düzeyde olduğu, uygulama yapma imkânının olmadığı ve ders materyali geliştirme sürecine ağırlık verilmesi gerektiği şeklinde farklı temalar ortaya çıkmıştır. Öğretmen adaylarının büyük çoğunluğu (n=36) derste video, görüntü, canlandırma vb. etkinliklere daha fazla yer verilmesi gerektiğini ifade etmektedirler. Bu konudaki görüşlerden bazıları şu şekildedir: "Kesinlikle video, görüntü, canlandırma gibi etkinliklerin daha fazla olması gerektiğini düşünüyorum." $\left(\ddot{O}_{1}\right)$; “Özel ĕgitim alan ögrencilere nasıl müziği daha iyi ögretebileceğimizle canlandirma yapma ve bu konuyla ilgili görüntü, video izlemek bu dersi bizim için daha verimli hale getirirdi." $\left(\ddot{O}_{40}\right)$. Öğretmen adaylarından bazıları etkinliklerin nasıl yapılması gerektiğine dair detaylara yer vermiştir. Aşağıda öğretmen adaylarının ifadelerinden örnekler alıntılanmıştır: "Özellikle kendi alanım ile ilgili örnek dersler, uygulamalar izleseydim ileride karşılaştığım durumlardaki sergileyeceğim yaklaşımda büyük değişiklikler yaratacă̆ını düşünmekteyim." $\left(\ddot{O}_{41}\right)$. "Müzik olarak genelleyecek olursak, yetersizliği olan bireylere müzik eğitimi konusunda yapılan çalışmalardan örnekler izlemenin de bizim gelişmemize katkı sağlayacağını düşünüyorum." (Ö${ }_{23}$ ). Yukarıdaki görüşlerin aksine bir grup öğretmen adayı (5) dersteki görsel içeriğin yeterli düzeyde olduğunu belirtmiştir. Örneğin Ö ${ }_{4}$ "Ders içeriğinde yeterince görsel içerik olduğunu düşünüyorum."; ${ }_{16}$ "Derste kullanılan görsellerinde çok yeterli olduğunu ve gerçekten verimli olduğunu düşünüyorum.” şeklinde açıklama yapmıştır.

Öğretmen adaylarından bazıları ( $\mathrm{n}=9)$ uzaktan eğitimle yürütülen ders süresince uygulama yapma imkânlarının olmadığını dile getirmişlerdir. ${ }_{12}$ "Uygulama açısından özel eğitim alan bir ögrenciyle ya da engelli, yetersizliği ve özrü olan bir birey ile ders yapma şansım olmadı. Teorik olarak aldiğımız bilgileri özel ĕgitim ögrencisinde uygulama firsatımız olmadiğını düşünüyorum." (Ӧ 24$)$.

İki öğretmen adayı ders materyali geliştirme sürecine ağılık verilmesi gerektiğini belirtirken, görüşlerini "Öğretmenlerin alanlart ile ilgili verdikleri özel eğitiminde ders 
materyali geliştirme konusundaki ĕgitimi konularına daha fazla ağırlık verilebilirdi." (Ӧ şeklinde ifade etmişlerdir.

\section{6. Öneriler/İstekler}

Öğretmen adaylarına son olarak “Eklemek istediğiniz veya önereceğiniz herhangi bir şey var mı?" sorusu yöneltilmiştir. Bu kapsamda farklı görüşler elde edilmiştir.

Öğretmen adaylarının öneri/istek olarak sundukları temalardan ilki öğretmenlerin tecrübe ve izlenimlerini dinleme yönündedir $(\mathrm{n}=4)$. "Öğretmenlerin konuya ilişkin tecrübelerini ve izlenimlerini dinlemenin iyi bir öneri olduğunu düşünüyorum." $\left(\ddot{O}_{1}\right)$; "Bu ögrencilerle etkileşim halinde olan müzik ögretmenlerinin tecrübelerini anlattı̆g bölümler olsaydı daha etkileyici olurdu." $\left(\ddot{\mathrm{O}}_{3}\right)$.

İkincisi müzik eğitimi alanına yönelik ayrı bir dersin daha olması gerektiği yönündeki görüşlerdir ( $\mathrm{n}=6)$. "Alanımıza yönelik nasıl özel eğitim vereceğimize dair farklı bir ders olması gerektiğini düşünüyorum." (Ӧ$\left.{ }_{4}\right)$; "Özel eğitimde müzik uygulamaları adlı bir ders açılması biz müzik ögretmeni adayları için çok faydall olabilir. Özel eğitim dersiyle ikisi farkl şeyler." (Ö̈31).

Üçüncü grup doğrudan okullarda gözlem/uygulama yapabilme isteğidir (n=13). Ö22 "Bir özel eğitim okuluna gidip örnek bir basit müzik dersi/uygulaması yapılabilir."; ${ }_{47}$ "Bir an olsun işi sahasında deneyimleyebilmek veya sadece görmek bile yetebilirdi diye düşünüyorum. "; $\ddot{\mathrm{O}}_{22}$ "Daha fazla pratiğe dayall ve uygulamalı eğitim yapabilme şansımı olsa daha iyi tecrübe edebileceğimizi düşünüyorum." ş̧eklinde görüşlerini belirtmişlerdir.

Dördüncüsü özel gereksinimi olan öğrencilerle doğrudan iletişim kurabilmedir $(n=4)$. Ö 29 görüşlerini "Her ne kadar izlesek de teorik olarak ögrensek de yakından bir öğrenciyi tanırsak onunla etkileşim içerisinde olsak en etkili en verimli öğrenmeyi gerçekleştireceğimizi düşünüyorum. "şeklinde ifade etmiştir.

Beşinci kategoride öğretmen adayları tartışma, ortak fikirler geliştirme, araştırma yapma gibi özelliklere dikkat çekmişlerdir $(\mathrm{n}=7)$. $\ddot{O}_{11}$ "Bu alanda yapılan çalışmaların derslerimizde daha çok üzerinde durulmall ve ortak fikirlerce gelişstirilmeliydi."; $\ddot{O}_{24}$ "Karşıllkl olarak fikir yürüterek dersin işlenmesini tercih ederdim. Özel eğitim alanındaki bilgiler ve deneyimler ile bizim müzik eğitimi alanındaki bilgilerimiz birleştirilerek dersin işlenmesi bizim açımızdan daha yararlı olabilirdi." şeklinde görüş bildirdikleri görülmektedir.

Son kategori öğretmen adaylarının işaret dili (1) ve braille alfabesinin $(\mathrm{n}=2)$ öğrenilme isteği ile ilgilidir. Bu konuda $\ddot{O}_{13}$ "Bu derste Türk İşaret Dili ögrenmek isterdim."; ${ }_{24}$, "Braille alfabesini daha fazla çözümleyebilirdik. Ben bunu öğreneceğimizi düşünmüştüm.”; Ӧ 37 "Derslerde braille notalarını öğrenebilirdik." şeklinde önerisini dile getirmiştir.

\section{TARTIŞMA VE SONUÇ}

Ülkemizde son yıllarda kaynaştırma uygulamalarına daha fazla yer verildiği bilinmektedir. Bunun bir sonucu olarak örgün eğitim kurumlarına devam eden özel gereksinimli öğrencilerin (kaynaştırma öğrencileri) sayısı artış göstermektedir (MEB, 2020). Kaynaştırma eğitiminde sanat çalışmaları içerisinde müzik derslerinin dolayısıyla müzik öğretmenlerinin önemli bir rolü bulunmaktadır (Uçal-Canakay, 2020). Çünkü bu ders aracılığıyla, özel gereksinimli öğrencilerin sosyalleşmesi sağlanabilmekte aynı zamanda toplumsal uyum becerileri kazandırılabilmektedir. $\mathrm{Bu}$ durum, yapılan çalışmada bazı öğretmen adayları tarafından kısmen vurgulanmıştır. Örneğin, özellikle kaynaştırma öğrencileri ile çalışabilme/karşılaşabilme olasılıkları olduğuna dkkat çekmişlerdir. $\mathrm{Bu}$ bağlamda, müzik öğretmeni adayları kendi alanlarından yola çıkarak özel eğitim dersinin kendilerinden ziyade her öğretmen için gerekli olduğu yönünde görüş bildirmişlerdir. Benzer bir bulgu Çitil vd. (2018) tarafindan yapılan araştırmada gözlenmiş ve özel eğitim dersi tüm öğretmen adaylarına 
önerilmiştir. Nitekim, özel eğitim alanının farklı branş uzmanları tarafından da kavranabilmesi amacıyla birçok öğretmenlik programında özel eğitim dersi verilmektedir. Sonuç olarak, müzik öğretmeni adaylarının özel gereksinimli öğrencilerle çalışma ihtimali konusunda kısmen de olsa farkındalık sahibi oldukları söylenebilir. Ayrıca bu farkındalıkları aldıkları özel eğitim dersinden sonra da artmış olabilir. Özel gereksinimli öğrenciler hakkında farkındalık yaratması, bu öğrencileri fark edilebilmeleri ve eğitsel açıdan destekleyebilmeleri açısından özel eğitim dersinin önemli olduğu düşünülmektedir (Çitil vd., 2018). Nitekim bazı öğretmen adayları tarafından özel eğitim dersinde pek çok yeni bilginin öğrenildiği dile getirilmiştir. Bu bilgiler arasında uyarlama, kaynaştırma, sınıf yönetimi, etkili öğretim yöntemleri, materyal kullanımı gibi önemli konular yer almaktadır. Dolayısıyla öğrenilen bilgilerin bu dersin gerekli olduğu yönünde bir farkındalık oluşturmuş olabileceği düşünülebilir. Bununla birlikte öğretmen adaylarının yarıya yakını özel eğitim dersinin faydalı olduğu, neredeyse tamamına yakını ise bu dersin meslek yaşantılarına katkı sağlayacağı yönünde görüş bildirmiştir. Bu görüşler öğretmen adaylarının almış oldukları özel eğitim dersinin önemine işaret etmektedir. Son olarak, öğretmen adaylarına sunulan özel eğitim dersinin meslek hayatlarına katkı sunması ile beraber özel gereksinimli öğrencilere yönelik tutumlarını olumlu yönde etkilemesi beklenmektedir (Yaral1, 2016). Yapılan çalışmada her ne kadar öğretmen adaylarının tutumları bakımından bir değerlendirme yapılmamış olsa da alınan geri bildirimlerin olumlu yönde olduğu söylenebilir. Ancak bu durum sadece araştırmacının düşüncelerine dayanmaktadır. Bu nedenle, bir sınırlılık bağlamında ele alınabilir.

Çalışmada, öğretmen adaylarının özel eğitim dersinden çeşitli konularda beklentilerinin olduğu tespit edilmiştir. Örneğin özel gereksinimli öğrencileri tanıyabilmek, derse katabilmek, fark edebilmek, destekleyebilmek, iletişim kurabilmek gibi farklı beklentiler ortaya çıkmıştır. Genel olarak özel eğitim derslerinin içeriğinde tanımlar, ilkeler, nedenler, erken tanı, tarihsel yaklaşım, yetersizlik türlerinin özellikleri ve eğitimleri, aileler, kurum ve kuruluşlar, kaynaştırma gibi çeşitli konu başlıkları yer almaktadır. Bu anlamda, özel eğitim dersinin öğretmen adaylarının hem özel eğitim hakkında hem de özel gereksinimli öğrenciler hakkında yeterli bilgi sahibi olmalarını sağlayacak geniş bir içeriğe sahip olduğu söylenebilir (Durdukoca-Fırat, 2015; Yaralı, 2016). Bu anlamda öğretmen adaylarının almış olduğu ders neticesinde beklentilerinin karşılanmış olabileceği düşünülmektedir. Çalışmaya katılan öğretmen adaylarının büyük çoğunluğu ders sonunda beklentilerinin önemli ölçüde karşılandığını belirtmişlerdir. Dolayısıyla uzaktan eğitimle verilen özel eğitim dersinin öğrencilerin beklentilerini karşılama konusunda etkili olduğunu yorumu yapılabilir. Özel eğitim dersinin içeriğinde detaylı bilgiler yer aldığından dolayı, dersin içeriği önemli ölçüde etkilenmektedir. Çalışmaya katılan öğretmen adaylarının bir kısmı özel eğitim dersinde ele alınan konuları uzun ve detaylı bulmuşlardır. Bununla birlikte bir bölüm öğretmen adayı ise konuların üzerinde yeterince durulduğunu belirtmiştir. Ancak yine de söz konusu ders içeriğinin sunulmuş olmasına rağmen dersin hem haftalık hem de dönemlik açısından ders saatinin yetersiz olduğu belirtilmiştir. Ancak, özel eğitim dersinin haftalık ders saatinin iki saat olduğu, hatta uzaktan eğitim sürecinde bu sürenin daha da azaldığı göz önüne alındığında, ders süresiyle ilgili bu görüşler normal kabul edilebilir. Dolayısıyla uzaktan eğitim sürecinde ders sürelerinin arttırılması benzeri durumlar için bir öneri olarak sunulabilir. Bu sayede daha etkili ve verimli derslerin yürütülmesi sağlanabilir. Çitil vd. (2018) özel eğitim lisans dersinin kredi ve saatinin arttırılması ile dersin uygun bir içerik ve süreye sahip olması için gereken düzenlemelerin yapılmasında yarar bulunduğunu ifade etmektedir. Özel eğitim dersi birçok programda olduğu gibi teorik olarak işlenmektedir. $\mathrm{Bu}$ anlamda, dersin uzaktan eğitimle yürütülmesinin bir sınırlılık oluşturmayacağı düşünülmektedir.

Çalışmaya katılan öğretmen adaylarının bir bölümü müzik alanına ilişkin bazı konuların sınırlı kaldığı ve bu alana özgü konuların üzerinde daha fazla durulması gerektiği yönünde görüş bildirmiştir. Ancak, yukarıda da değinildiği üzere özel eğitim dersi birden fazla boyutu barındırdığından geniş bir içeriğe sahip olduğu ifade edilebilir. Bu içerik bazı istisnai durumları olmakla beraber genellikle özel eğitim bölümlerinde görev yapan öğretim elemanları tarafından 
yürütülmektedir. Dolayısıyla özel eğitim alt yapısından hareketle ders kapsamındaki içerikler aktarılmaktadır. Bu nedenle, söz konusu görüşe sahip öğretmen adaylarının bu görüşleri, alan odaklı bir beklenti içerisinde oldukları şeklinde yorumlanabilir. Bir grup öğretmen adayı müzik eğitimi alanına özgü ayrı bir özel eğitim dersinin olması gerektiğini belirtmişlerdir. Ancak bunun da özel eğitim dersi için uygulanmasının mümkün olmadığı ifade edilebilir. Özel eğitim dersi, genel itibariyle öğretmen adaylarının özel eğitim ve özel gereksinimli öğrencilere yönelik farkındalıklarının artması, mesleğe başladıktan sonra sınıflarında özel gereksinimli öğrencileri fark etmeleri, bu öğrencilerin eğitsel gereksinimlerini belirleyebilmelerine hizmet etmektedir. $\mathrm{Bu}$ yönüyle, özel eğitim dersi müzik özel alanından ziyade daha geniş ölçekli bir içeriği yansıtmaktadır. Ancak öğretmen adaylarının görüşlerinde de değinildiği gibi özel eğitim dersi haricinde programa farklı bir ders daha eklenerek öğretmen adaylarının bu beklentileri karşılanabilir. Bu anlamda söz konusu özel eğitim dersinin içeriği genişletilerek veya ek bir ders olarak iki farklı dönemde verilebilir. İlk döneminde teorik bazlı içerik sunulurken, ikinci döneminde ise uygulama ağırlıklı bir içerik sunulabilir (Çitil vd., 2018). Bazı öğretmen adayları uygulama yapma imkanlarının olmadığını açıklamışlardır. Yukarıda önerilen düzenleme ile öğretmen adaylarının uygulama imkanları arttırılabilir. Özel gereksinimli öğrencilerle çalışma deneyimleri kazanabilirler. Ancak çalışmanın ana temasından da sapmadan uzaktan eğitim içerisinde uygulama yapma şanslarının zaten olmadığını da unutmamak gerekir. Mevcut okulların (MEB), üniversitelerin vb. kapalı olması ve uzaktan eğitime devam ediyor olmaları da bu durumun en önemli sebeplerinden biri olarak gösterilebilir.

Uzaktan eğitimle yürütülen özel eğitim dersinin sunumu ile ilgili farklı görüşler ortaya çıkmıştır. Örneğin, çalışmaya katılan bir grup öğretmen adayı, uzaktan eğitimle yürütülen özel eğitim dersindeki görsel içereğin yeterli düzeyde olduğunu açıklamıştır. Ancak bu görüşlere karşın, öğretmen adaylarının büyük çoğunluğu, ders sürecinde canlandırma, görüntü gibi etkinlikler ile öğretim materyallerine daha fazla yer verilmesi gerektiğini ifade etmişlerdir. Ayrıca, bunların kullanılmasının öğrenmede daha faydalı olacağı, bilgilerin akılda daha çok kalacağı, konuların unutulmayacağ 1 , öğrenilenlerin somutlaştırılacağı, dersin daha iyi anlaşılmasını sağlayacağı yönünde görüşler öne çıkmıştır. $\mathrm{Bu}$ durum, müzik öğretmeni adaylarının uzaktan eğitim sürecinde daha fazla görüntü, video, canlandırma vb. uygulamalarına yönelik beklentilerini göstermektedir. Bilindiği üzere tüm dünyada olduğu gibi ülkemizde de etkisini gösteren pandemi nedeniyle yükseköğretim kurumları eğitim-öğretim faaliyetlerini gerçekleştirmek için uzaktan eğitim sürecine geçiş yapmışlardır. Uzaktan eğitime geçiş bu salgın sürecinde alınan en önemli tedbirlerden biri olarak ifade edilmektedir (Kalaç vd., 2020). Uzaktan eğitim çalışmaları genellikle web tabanlı uygulamalar üzerinden senkron ya da asenkron şekilde gerçekleştirilmektedir (Karatepe vd., 2020). Eşzamanlı olan veya olmayan çalışma prensibi, sağladığı zengin ders materyalleri ile bırakılan geniş alan da uzaktan eğitimin önemli avantajları olarak sıralanabilir (Kırık, 2014). Öte yandan, uzaktan eğitimle ilgili bazı sorunlar da yaşanmakta ve öğreten-öğrenen arasında etkileşimin sınırlı kalıyor olması önemli sorunlardan biri olarak açıklanmaktadır (Duran, 2020; Karakuş vd., 2020). Mevcut koşullara bakıldığında, çalışmaya katılan öğretmen adayları özel eğitim dersini senkron uygulamalar ile almışlardır. Dolayısıyla bu uygulamalar sayesinde çeşitli etkileşimlerin kurulduğu ve yüz yüze eğitimin sağlayacağı avantajların kısmen de olsa kullanıldı̆̆ varsayılabilir. Ancak öğretmen adaylarının görüşleri doğrultusunda bu avantajların sınırlı düzeyde kaldığı söylenebilir. Bu durumun etkisini en aza indirebilmek için özel eğitim dersinin uzaktan eğitimle verilmesi sırasında daha fazla görselin kullanılması, bununla beraber görüntü, video, canlandırma gibi uygulamalara daha fazla yer verilmesi önerilebilir. Ek olarak öğretim elemanları bu süreçte gereksinim duyabilecekleri özellikle uzaktan eğitim için materyal hazırlama, içerik oluşturma, teknik destek vb. konularda desteklenebilirler. Ayrıca elde edilen bulgulara farklı bir pencereden bakarak uzaktan eğitimin etkileşim boyutundaki sınırlılığının da göz önünde bulundurulması gerekir. Bu açıdan bu sınırlılığı en aza indirebilecek planlamaların yapılması önerilmektedir. Bu sayede uzaktan eğitimle yürütülen özel eğitim derslerinin daha etkili ve 
verimli olması sağlanabilir. Aynı zamanda öğretmen adaylarına da daha fazla kalıcı öğrenme yaşantıları sunulabilir.

\section{ÖNERÍLER}

Müzik öğretmeni adaylarının özel gereksinimli öğrencileri destekleyebilmek, ders içeriklerini planlayabilmek, çeşitli etkinlikler düzenleyebilmek, dersleri etkili ve verimli işleyebilmek gibi çeşitli amaçları yerine getirebilmeleri için yeterli bilgi ve donanıma sahip olmaları gerekmektedir. Bununla birlikte yüksek motivasyona sahip olmaları önem arz etmektedir. Dolayısıyla yapılan çalışmada müzik öğretmeni adayları ile yapılan görüşmeler sonucunda öğretmen adaylarının özel eğitim dersi hakkındaki genel kanaatlerinin olumlu yönde olduğu, geliştirilmesi veya üzerinde durulması gereken bazı hususlar olduğu görülmüştür. Bu yönüyle, uygulama açısından müzik eğitimi anabilim dalında verilen özel eğitim derslerinde farklı uygulamalara yer verilebilir. Bununla birlikte diğer branş öğretmenliklerinde verilen özel eğitim derslerinde de bu uygulamalar gerçekleştirilebilir. Bu çalışma uzaktan eğitimle yürütülen özel eğitim dersi üzerinden planlanmıştır. İleri araştırmalarda farklı değişkenler eklenerek araştırma boyutu genişletilebilir. Tutum, motivasyon, öz yeterlik, bilgi düzeyi vb. olmak üzere çeşitli faktörler bağımlı değişken olarak ele alınabilir. Farklı gruplardaki öğretmen adayları ile çalışmalar planlanabilir.

\section{KAYNAKÇA}

Akbayrak, K., Vural, G. ve Ağar, M. (2021). Özel eğitim öğretmenlerinin koronavirüs pandemisi döneminde uzaktan eğitime ilişkin deneyim ve görüşleri. İnönü Üniversitesi Eğitim Fakültesi Dergisi, 22(1), 471-499.

Alat, Z. ve Alat, K. (2007). Özel eğitim dersi almanın öğretmen adaylarının kaynaştırmaya yönelik tutumlarına etkisi. Poster bildiri. 16. Ulusal Eğitim Bilimleri Kongresi, Tokat, Türkiye.

Alptekin, S. ve Batık, M. V. (2013). Özel eğitim bölümü öğrencilerinin yetersizlikten etkilenmiş kişilere yönelik tutumlarına özel eğitim dersinin etkisi. e-International Journal of Educational Research, 4(4), 18-34.

Altıntaş, E. ve Şengül, S. (2014). Özel eğitim dersinin kaynaştırmaya yönelik tutumlar ve kazanımlar bakımından değerlendirilmesi. e-Kafkas Ĕgitim Araştırmaları Dergisi, 1(3), $1-12$.

Aslan, C. ve Kök, M. (2013). Özel ĕgitim dersinin ögrencilerin engellilere yönelik tutumlar üzerindeki etkisi. A. Konrot (Ed.) 23. Ulusal Özel Eğitim Kongresi Kongre Kitabı (s. 345346). Bolu. Türkiye.

Berki, T. ve Karakelle, S. (2009). 2006-2007 akademik yılında uygulamaya konulan merkezi müzik öğretmenliği lisans programının incelenmesi. 8. Ulusal Müzik Eğitimi Sempozyumu, Ondokuz Mayıs Üniversitesi Samsun. (23-25 Eylül).

Börnert-Ringleb, M., Casale, G., \& Hillenbrand, C. (2021). What predicts teachers' use of digital learning in Germany? Examining the obstacles and conditions of digital learning in special education. European Journal of Special Needs Education, 36(1), 80-97.

Büyüköztürk, Ş., Kılıç Çakmak, E., Akgün, Ö. E., Karadeniz, Ş. ve Demirel, F. (2012). Bilimsel araştırma yöntemleri. Ankara: Pegem.

Creswell, J. W. (2007). Qualitative inquiry and research design: Choosing among five approaches (2nd Edition). USA: SAGE. 
Creswell, J. W. (2016). Araştırma deseni. Nitel, nicel ve karma yöntem yaklaşımları. S. Beşir Demir (Çev. Ed.). Ankara: Eğiten.

Çay, E. (2020). Müzik eğitimi dersinin özel gereksinimli öğrencilere katkısının özel eğitim öğretmenlerinin görüşleriyle belirlenmesi. Muallim Rıfat Eğitim Fakültesi Dergisi, 2(1), 60-79.

Çitil, M., Karakoç, T. ve Küçüközyiğit, M. S. (2018). Özel eğitim lisans dersinin öğretmen adaylarının bilgi düzeylerine ve engellilere yönelik tutumlarına etkisi. Abant İzzet Baysal Üniversitesi Ĕgitim Fakültesi Dergisi, 18(2), 815-833.

Duran, L. (2020). Distance learners' experiences of silence online: a phenomenological inquiry. International Review of Research in Open and Distributed Learning, 21(1), 81-98.

Durdukoca-Fırat, Ş. (2015). Özel eğitim dersine yönelik tutum ölçeğinin geliştirilmesi. Turkish Studies, 10(11), 651-666.

Durdukoca-Fırat, Ş. (2017). Özel eğitim dersinde örnek olay inceleme yönteminin öğrenenlerin üstbilişsel farkındalıklarına, derse yönelik tutumlarına ve görüşlerine etkisi: Bir karma yöntem araştırması. Kastamonu Eğitim Dergisi, 25(4), 1267-1284.

Frederick, J. K., Raabe, G. R., Rogers, V. R., \& Pizzica, J. (2020). Advocacy, collaboration, and intervention: A model of distance special education support services amid COVID19. Behavior Analysis In Practice, 13, 748-756.

Heward, W. L., Alber-Morgan, S., \& Konrad, M. (2017). Revel for exceptional children: An introduction to special education with loose-leaf version. Pearson.

Kalaç, M. Ö., Telli, G. ve Eronal, Y. (2020). Covid-19 mücadelesi kapsaminda uzaktan eğitim sürecinde engelli öğrencilerin durumu sorunlar ve çözüm önerileri. Manisa: Manisa Celal Bayar Üniversitesi.

Kalyoncu, N. (2004). Müzik ögrretmeni yeterlikleri ve güncel müzik ögretmenliği lisans programı. 1924-2004 Musiki Muallim Mektebinden Günümüze Müzik Öğretmeni Yetiştirme Sempozyumu'nda sunulmuş bildiri. 7-10 Nisan, Isparta.

Kan, A. Ü. ve Fidan, E. K. (2016). Türk dili dersinin uzaktan eğitimle yürütülmesine ilişkin öğrenci algıları. Turkish Journal of Educational Studies, 3(2), 23-45.

Karakuş, N., Ucuzsatar, N., Karacaoğlu, M. Ö., Esendemir, N. ve Bayraktar, D. (2020). Türkçe öğretmeni adaylarının uzaktan eğitime yönelik görüşleri. RumeliDE Dil ve Edebiyat Araştırmaları Dergisi, 19, 220-241.

Karatepe, F., Küçükgençay, N. ve Peker, B. (2020). Öğretmen adayları senkron uzaktan eğitime nasıl bakıyor? Bir anket çalışması. Journal of Social and Humanities Sciences Research, 7(53), 1262-1274.

Kırık, A. M. (2014). Uzaktan eğitimin tarihsel gelişimi ve Türkiye'deki durumu. Marmara İletişim Dergisi, 21, 73-94.

Kizir, M. (2021). İnternet temelli özel eğitim hizmeti alan bireylerin uzaktan eğitime yönelik görüşlerinin belirlenmesi. Muğla Sitkı Koçman Üniversitesi Eğitim Fakültesi, 8(1), 165181.

Koşar, S. (2018). Geçerlik ve güvenirlik. K. Beycioğlu, N. Özer ve Y. Kondakçı (Ed.), Eğitim yönetiminde araştırma içinde (s. 169-200). Ankara: Pegem.

Kösterelioğlu, İ. ve Baytemir, K. (2017). Psikolojik danışma ve rehberlik öğrencilerinin özel eğitim dersi sürecindeki kazanımlarının belirlenmesi. Marmara Üniversitesi Atatürk Eğitim Fakültesi Ĕ̈itim Bilimleri Dergisi, 44, 53-71. 
Melekoğlu, M. (2011). Farklı branşlardan öğretmen adaylarl için özel eğitim derslerinin etkililiğini geliştirmek amaçlı bir uygulama: Özel gereksinimli öğrencilerle etkileşim projesi. 21.Ulusal Özel Eğitim Kongresi, 20-22 Ekim, Gazimağusa, KKTC.

Miles, M. B. ve Huberman, A. M. (2015). Nitel veri analizi: Genişletilmiş bir kaynak kitap. S. Akbaba-Altun ve A. Ersoy (Çev. Ed). Ankara: Pegem.

Milli Eğitim Bakanlı̆̆ı [MEB]. (2020). Millî eğitim istatistikleri, Örgün Eğitim 2019/'20. http://sgb.meb.gov.tr/meb_iys_dosyalar/2020_09/04144812_meb_istatistikleri_orgun_egi tim_2019_2020.pdf adresinden erişilmiştir.

Patton, Q. M. (2014). Nitel araştırma ve değerlendirme yöntemleri (Çev.: M. Bütün \& S. B. Demir). Ankara: Pegem.

Sani-Bozkurt, S., Bozkuş-Genç, G., Vuran, S., Yıldız, G., Çelik, S., Diken, İ. H., Uysal, Ç., Gürgür, H., Kalayc1, G. Ö., Diken, Ö., Ateşgöz, N. N., İçüzz, R., Doğan, M., Şafak, P. ve Demiryürek, P. (2021). COVID-19 salgınında Türkiye'deki özel gereksinimi olan öğrenciler ve ailelerine yönelik uzaktan özel eğitim uygulamalarına ilişkin uzman bakış açısı. Ankara Üniversitesi Ĕ̈itim Bilimleri Fakültesi Özel Ĕ̈itim Dergisi, Erken Görünüm. https://doi.org/10.21565/ozelegitimdergisi.786118

Sarı, H. ve Saygın, F. (2002). Üniversite öğrencilerinin özel eğitim dersi etkinlikleri almalarına yönelik ihtiyaçların analizi. XI. Ulusal Eğitim Kongresi Bildirileri.

Top, E. (2018). 14 haftalık özel eğitim dersi uygulamasının üniversite öğrencilerinin empatik eğilim ve engellilere yönelik tutumlarına etkisi. Spor ve Performans Araştırmaları Dergisi, 9(3), 174-183.

Uçal-Canakay, E. (2020). Kaynaştırma eğitimine yönelik müzik öğretmeni özyeterliği ölçeği geçerlik-güvenirlik çalışması. Batı Anadolu Eğitim Bilimleri Dergisi, 11(1), 195-210.

Uçan, A. (2018). Müzik eğitimi temel kavramlar-ilkeler-yaklaşlmlar ve Türkiye'deki durum. Ankara: Arkadaş.

Ünay, E., Erdem, R. ve Çakıroğlu, O. (2021). Covid-19 sürecinde özel eğitimde uzaktan eğitim uygulamaları. Uludă̆ Üniversitesi Eğitim Fakültesi Dergisi, 34(Özel Say1), 158-184.

Ünver, G., Bümen, N. T. ve Başbay, M. (2010). Ortaöğretim alan öğretmenliği tezsiz yüksek lisans derslerine öğretim elemanı bakışı: Ege Üniversitesi örneği. Eğitim ve Bilim Dergisi, 155(35), 63-77.

Varış, Y. (2013). Müzik öğretmeni adaylarının okul deneyimi üzerine görüşleri. Marmara Üniversitesi Atatürk Eğitim Fakültesi Eğitim Bilimleri Dergisi, 33(33), 177-191.

Yaralı, D. (2015). Özel eğitim dersine ilişkin ölçek geliştirme çalışması: Geçerlik ve güvenirlik. e-Kafkas Ë̆itim Araştırmaları Dergisi, 2(2), 12-22.

Yaralı, D. (2016). Öğretmen adaylarının özel eğitim dersine yönelik tutumlarının bazı değişkenler açısından incelenmesi. Pamukkale Üniversitesi Sosyal Bilimler Enstitüsü Dergisi, 24, 59-76.

Yıldırım, A. ve Şimşek, H. (2005). Sosyal bilimlerde nitel araştırma yöntemleri. Ankara: Seçkin.

Yükseköğretim Kurulu [YÖK]. (2020). YÖK başkanı saraç üniversitelerde verilecek olan uzaktan eğitime ilişkin açıklama yaptı. www.yok.gov.tr/Sayfalar/Haberler/2020/ universitelerde-uygulanacak-uzaktan-egitime-iliskin-aciklama.aspx $\quad$ E.T: $\quad$ 16.04.2020. adresinden erişilmiştir. 


\section{EXTENDED ABSTRACT}

\section{Introduction}

Special education course is one of the lessons that are traditionally carried out face-toface in a classroom environment. However, due to the coronavirus pandemic (COVID-19) affecting the whole world, this course is offered in distance education. In the face of this situation experienced by our country with the transition to distance education applications, studies regarding distance education are of great importance. This study was planned considering this importance. Therefore, the study focused on prospective music teachers who took the special education course with distance education. The continuation of the COVID-19 pandemic and distance education practices under current conditions reflects the contemporary aspect of this study. When the literature is examined, there is no research directly examining this issue. In this regard, the study is considered essential and expected to contribute to the literature. In the study, the researcher thinks about the conduct of the special education course with distance education. He believed that it could make evaluations regarding the content of the course and its contribution to music education in the process of student-lecturer interaction. Also, he can examine the outcomes of the application. In short, this study aims to determine the opinions of prospective music teachers regarding the special education course conducted with distance education.

\section{Methods}

The researcher constructed according to phenomenology, one of the qualitative research models. Forty-seven prospective music teachers constituted the participants of the study. A semi-structured interview form, which the researchers prepared, was used to collect data. The researcher collected the data in the 2019-2020 academic year. During the data collection process, he first obtained the necessary ethical and legal permissions. Then, he used the Learning Management System provided by the Distance Education Application and Research Center of the relevant university for data collection. The data collection process of this study was carried out by the distance education method. He obtained opinions about the special education course conducted with distance education based on the written statements of the prospective teachers. Content analysis technique was used in the analysis of the obtained data. The answers given by the future teachers to the questions were read one by one by the researcher, and he determined the significant parts in the data. Later, these parts were examined again and marked with a concept, word, or sentence that would best express these parts. Thus, the interview texts started to be analyzed. In this context, the written transcripts of the interviews were coded for the study. Then, the researcher classified the coded data and created themes/categories to represent these codes best. Finally, the data were reported by dividing them into themes and sub-themes. In coding the data obtained in qualitative research, inter-coder reliability analysis is performed, and the reliability is expected to be in the $90 \%$ range (Miles and Huberman, 2015). In this study, the researcher found a $91 \%$ consensus due to the evaluation made using the formula "Reliability = Consensus / (Total Consensus + Total Disagreement)."

\section{Results and Discussion}

According to the study's findings, the researcher concluded that a special education course is necessary and valuable for every teacher and will contribute to professional life. He observed that prospective teachers had some expectations from the special education course, and they met these expectations at the end of the course to a great extent. However, different opinions emerged about how the course was taught and the topics covered in the course. For example, in the special education course, prospective teachers learned a lot of new information. The topics covered in the course were long and detailed, but they emphasized all topics were enough. However, some music-related issues were limited during the course. The instructors should have noted the subjects specific to this field more. It was also determined that the content 
was at a sufficient level. The focus should be on material development during the lesson, activities such as animation and images should be used more, and there was no opportunity to practice the course.

Therefore, music lessons and teachers have an essential role in art studies in inclusive education (Uçal-Canakay, 2020). This lesson enables students with special needs to socialize and at the same time gain social adaptation skills. Some prospective teachers in the study partially emphasized this situation. For example, although they stated that they would not work in special education schools, they expressed the possibility of working/meeting, especially with inclusive students. In this context, they stated that the special education course was necessary for them and every teacher. In this sense, it is thought that prospective teachers' expectations may have been met as a result of the course they have taken. Most of the prospective teachers who participated in the study stated that their expectations were met at the end of the lesson. Therefore, it can interpret that the special education course offered with distance education effectively meets the students' expectations. Since there is detailed information in the special education lesson's content, the lesson's volume is significantly affected. Some prospective teachers who participated in the study found the topics covered in special education courses long and detailed. However, some future teachers stated that the subjects were sufficiently emphasized. However, although the subject course content was presented, it was stated that both the weekly and semester duration of the course was insufficient. In this regard, the special education course reflects a broader content than the special field of music. However, as mentioned in the opinions of prospective teachers, they can meet these expectations by adding a different special education course to the program. In this sense, the content of the special education course in question can be expanded or given as an additional course in two different semesters. 